\title{
Entrevista com Tarso Genro
}

Cristina Buarque de Hollanda

\section{Tarso Genro}

Advogado e professor universitário. Foi deputado federal $(1989,1990-$ 1991), duas vezes prefeito de Porto Alegre (1993-1996; 2001-2002), foi Ministro da Educação (2004-2005) e Ministro das Relações Institucionais (2006-2007) do primeiro governo Lula. Depois, Ministro da Justiça (20072010) no segundo mandato do mesmo Presidente e governador do Rio Grande do Sul (2011-2015).

\section{Cristina Buarque de Hollanda}

Professora do Instituto de Estudos Sociais e Políticos da Universidade do Estado do Rio de Janeiro.

E-mail: cristinabuarque@gmail.com

ORCID: https://orcid.org/0000-0002-1600-4044

\section{CRISTINA BUARQUE DE HOLLANDA:}

Olá Tarso. Muito obrigada por aceitar este convite para entrevista em plena quarentena.

\section{TARSO GENRO:}

É um prazer, Cristina. Podemos conversar por bastante tempo e espero poder ajudar no seu trabalho.

\section{CRISTINA BUARQUE DE HOLLANDA:}

Tarso, eu proponho começarmos do começo. O senhor poderia comentar um pouco do início precoce e conturbado da sua carreira política? Eu fiquei muito surpresa ao saber que o senhor foi eleito para a Câmara de Santa Maria - me corrija se eu estiver errada - aos dezenove anos de idade, em 1966, e exerce parte deste mandato já em plena ditadura. Depois o senhor renuncia em 1970 e em seguida vai para o exílio no Uruguai. Como foram estes anos na Câmara de Santa Maria e, depois, a renúncia e o exílio?

\section{TARSO GENRO:}

Bom, eu sou filho de um pai que era professor estadual e a minha mãe, apesar de ser uma pessoa intelectualizada, trabalhava em casa, cuidando dos filhos. Nós éramos seis filhos e nessa escadinha eu sou o terceiro. Meu pai era do Partido Trabalhista Brasileiro [PTB], muito ligado ao Presidente João Goulart, era amigo pessoal dele, inclusive. Eu nasci em São Borja e meu pai era professor em São Borja e se articulava muito com o movimento trabalhista a partir do João Goulart. Inclusive o João Goulart foi uma das motivações pelas quais ele passou a lutar politicamente no PTB. Meu pai saía sempre para as reuniões políticas: foi vereador, viceprefeito de Santa Maria, era líder do PTB lá. Então, a minha mãe sempre pedia que, quando meu pai saísse para fazer política, que me levasse junto, porque eu era muito agitado. Como terceiro, era uma descendência inquieta e muito agitada em casa. Por isso minha mãe dizia: "pelo amor de Deus, leva o Tarso!" E eu comecei a gostar, desde os meus treze ou quatorze 
anos, daqueles encontros. Eu admirava as reuniões políticas, os debates, os temas que por ali passavam. Com isso, eu entrei na chamada Mocidade Trabalhista, ligada ao PTB.

Posteriormente, vários de nós entramos em organizações clandestinas de resistência ao regime militar e ficamos por assim dizer infiltrados dentro do Partido Trabalhista e, depois, dentro do MDB [Movimento Democrático Brasileiro], naquelas ações de política de infiltração. Eu fui candidato a vereador pela sigla do MDB e, neste relacionamento politico, nós entramos na campanha de autodissolução do MDB em articulação com uma série de lideranças regionais que queriam fazer uma denúncia total da ditadura militar, para o exterior, inclusive. Com essa movimentação, eu já era vereador, me elegi vereador, e foi uma eleição muito fortalecida pela cassação que meu pai sofreu como vice-prefeito de Santa Maria. Na eleição seguinte, me elegeram. Eu não tinha prestígio suficiente para me eleger vereador, me elegi com o prestígio do meu pai: fui o segundo mais votado com 19, 20 anos em Santa Maria. Quando nos elegemos vereadores, nós combinamos o ato de autodissolução de vários vereadores e dirigentes políticos. A ideia era renunciar e fazer um manifesto de denúncia do regime militar, que não nos dava condições de exercer o mandato plenamente. Tanto é que tinham sido cassados três colegas meus, da nossa bancada, o que nos exigia um movimento de solidariedade. Mas, no fim, este movimento de renúncia furou e só as pessoas mais organizadas e radicais contra o regime é que largaram a Câmara dos Vereadores. E a partir deste momento a minha militância ficou toda vinculada ao trabalho clandestino. Nós herdamos, lá em Santa Maria, o velho Partidão, que foi desorganizado. Todas as suas lideranças foram presas e nós entramos neste vácuo do Partidão. Eu com 21 ou 22 anos.

\section{CRISTINA BUARQUE DE HOLLANDA:}

Como era a experiência de vida clandestina vivida em simultâneo com a vida de vereador de Santa Maria?

\section{TARSO GENRO:}

Foi uma dupla vida. Uma foi mantida na legalidade, onde eu era próximo ao MDB, e a outra foi clandestina. Eu mergulhava na clandestinidade com o nome reservado para não ser reconhecido legalmente. Quando eu renunciei, já estava em curso ou logo depois saiu, já não me lembro bem, o Ato Institucional número 5. A partir disso, nós continuamos com a organização do nosso trabalho no meio sindical, da intelectualidade e da cultura, com as nossas organizações fechadas. Nós não estávamos vinculados diretamente a nenhuma ação militar armada, embora tivéssemos uma perspectiva de que mais tarde isso seria necessário. Com esta estratégia de atividades, conseguimos organizar todo um trabalho político no Rio Grande do Sul, que mais tarde vai ser constituído novamente a partir de 1980, 82, com a fundação do Partido Revolucionário Comunista [PRC], que foi uma das dissidências comunistas da qual eu participei de maneira muito organizada e por mais de dez anos. Nesse intervalo eu tive que me exilar no Uruguai, porque aquele grupo comunista ao qual eu estava ligado começou a ser preso - em São Paulo, pessoas foram torturadas, algumas pessoas foram eliminadas, inclusive. Eu não sabia se teria condições de resistir à tortura. Tinha muitas pessoas que me conheciam e estavam soltas, então eu procurei sair do país para evitar entrar no processo de tortura. E foi bom eu ter saído porque a partir da minha saída ninguém mais foi preso, porque eles iam fazendo um processo a partir das informações que extraíam dos presos sob tortura e violência no interrogatório. As pessoas não iam resistindo e iam falando. Poucas eram as pessoas que 
ENTREVISTA COM TARSO GENRO

REVISTA ESTUDOS POLÍTICOS Vol. 10 | N.2 ISSN 2177-2851 Cristina Buarque de Hollanda

efetivamente traíam, o que ocorria era que as pessoas não aguentavam a tortura e iam cedendo informações sobre seus companheiros para salvarem suas próprias vidas. Uma coisa completamente compreensível, embora condenável para quem entrava num tipo de trabalho como este. Eu estive por quase dois anos no Uruguai e quando o meu inquérito foi para a Justiça Militar eu me apresentei para responder o processo e pude respondê-lo mais ou menos abrigado com interrogatórios feitos no DOPS [Departamento de Ordem Política e Social], mas sem violência.

\section{CRISTINA BUARQUE DE HOLLANDA:}

O senhor lembra em que ano se deu este processo?

\section{TARSO GENRO:}

A minha volta do Uruguai foi em 73, entre o fim de 72 e começo de 73 . O meu julgamento foi no fim de 74 , quando fui absolvido por falta de provas, juntamente com outras pessoas algumas absolvidas como eu e outras condenadas. Foi o chamado processo da Ala Vermelha, do Rio Grande do Sul, que era a organização da qual eu participava naquele momento. Após a minha volta ao Uruguai eu voltei a trabalhar com meu pai, como advogado trabalhista, e daí fui para Porto Alegre e lá retomei este trabalho clandestino todo, num outro nível, num outro tipo de organização, com outros companheiros e com outras metas políticas naquele momento. $\mathrm{E}$ fiquei ligado ao MDB, ato que a gente chamava na época de "ficar com a dupla camiseta". E depois, em 84, nós entramos no PT e, finalmente, em 1990, nós finalmente dissolvemos o PRC e encaramos o PT não mais como um partido-infiltração ou partido-pátio, como a gente dizia, mas como um partido voltado para a democracia, como um partido político integrado na legalidade que se mostrou na superfície da luta política com um compromisso com a legalidade e com a Constituição de 1988. Essa é a minha sequência. Depois eu fui deputado federal e viceprefeito. Depois de um intervalo, voltei a ser prefeito novamente. E depois entrei no Ministério do Lula, fui organizador do "conselhão": Conselho de Desenvolvimento Econômico-Social. Em seguida, eu fui para o Ministério da Educação, onde estive por quase dois anos. Depois disso, eu saí com aquela crise do partido. Fui presidente do partido e convoquei as suas eleições internas, que regularizaram novamente a vida do partido, que seguiu adiante depois disto. A partir daí eu voltei para o governo, fui Ministro de Relações Institucionais do Presidente da República, do governo, no ano da reeleição do Lula. E depois desse Ministério, eu fui para o Ministério da Justiça e fiquei até ser candidato e ser eleito governador do estado do Rio Grande do Sul. Essa é a minha trajetória, de uma maneira muito superficial e sistemática. Uma trajetória que felizmente se sucedeu sem maiores problemas, porque eu consegui ficar no Uruguai naquela fase crítica e por isso consegui não ser torturado nem abrir ninguém. E depois consegui desenvolver uma atividade profissional muito intensa na advocacia trabalhista junto à classe trabalhadora, onde eu combinei a minha atividade política com a profissional, porque eu era advogado do sindicato. Eu inclusive fui delegado no primeiro congresso nacional da CUT [Central Única dos Trabalhadores]. Nós tínhamos um conjunto de relações junto à classe trabalhadora que nos permitiu ajudar bastante a organização do PT em Porto Alegre e nos proporcionou participar de todas as lutas políticas que a gente desenvolveu a partir dali. E aqui estou, dando este depoimento. 
ENTREVISTA COM TARSO GENRO

REVISTA ESTUDOS POLÍTICOS Vol. 10 | N.2 ISSN 2177-2851 Cristina Buarque de Hollanda

\section{CRISTINA BUARQUE DE HOLLANDA:}

Se o senhor me permite voltar para a ditadura e para a época do seu exílio, eu gostaria de fazer duas perguntas. Primeiro, o senhor mencionou muito brevemente o horizonte da luta armada como possível, mas ao qual o senhor finalmente não aderiu. Qual era e qual foi, ao longo do percurso da ditadura, a sua avaliação sobre a luta armada? E como foi, depois do seu retorno, seu engajamento na resistência à ditadura? O senhor se envolveu, por exemplo, com a campanha pela anistia?

\section{TARSO GENRO:}

Veja, dentro da esquerda, não existe somente uma visão vinculada à questão da luta armada.

\section{CRISTINA BUARQUE DE HOLLANDA:}

Claro.

\section{TARSO GENRO:}

Hoje não existe um projeto de luta armada. Todos os grupos de esquerda, ou 99\% dos grupos de esquerda, foram assimilados no estado democrático de direito, no estado social de direito e na legalidade democrática. Eles começaram a participar dela: os partidos socialdemocratas, partidos comunistas, as organizações trotskistas e assim por diante. Mas naquela época existia um projeto de luta armada, porque havia um entendimento na ampla maioria da esquerda, com exceção do Partidão, de que a ditadura militar não iria ceder terreno para a democracia e que obrigatoriamente ela teria que ser derrubada por um movimento revolucionário. Esta era uma concepção mais ou menos unitária em todos os movimentos de esquerda clandestinos. Só que os processos táticos e estratégicos do desencadeamento deste enfrentamento eram diferentes. O PC do B, por exemplo, defendia a guerrilha a partir do campo. O grupo do qual eu participava, que em sua origem era uma dissidência do PC do $B$, entendia que isso era uma concepção errada, porque acreditavam que não seria possível recuperar o Brasil com aqueles métodos de luta que ocorreram no Vietnã e na Revolução Chinesa. Nós não tínhamos um campesinato capaz de se organizar com esta intencionalidade. Outros grupos entendiam que a revolução não viria de uma guerra popular no campo, como dizia o PC do B, mas da instalação de focos de guerrilheiros que promoveriam uma integração, uma metástase sócio-política, que iria envolvendo os contingentes do campo e eventualmente contingentes da cidade. Os focos de guerrilheiros que seriam o exemplo da luta armada. Outros grupos revolucionários entendiam que tinha que desencadear a luta armada na cidade para a partir da cidade dar exemplos, fazendo movimentações armadas para obter recursos para manter pessoas na clandestinidade, para eventualmente alugar aparelhos, comprar armas. O grupo em que eu estava naquela oportunidade não tinha nenhum envolvimento com estas atividades, porque o entendimento local que nós tínhamos era de que para desencadear qualquer coisa armada com uma mínima oportunidade de sucesso precisávamos de um apoio consciente e político do povo. Este grupo, em especial, não se envolveu em ações armadas no estado, o que nos permitiu uma sobrevivência da maioria dos nossos militantes, que depois foram se reencontrar dentro dos partidos políticos: primeiro dentro do PRC, depois dentro do PT, e assim por diante. A concepção mais refinada daquele momento era a do velho Partidão. Como dizia o Chico Buarque: "eu gosto do Partidão porque ele é uma espécie de carreta e sempre vai. Devagar, 
mas vai. Não leva as pessoas para a aventura." Eu ouvi o Chico dizer isso mais de uma vez. Então, essa concepção mais madura do Partidão também encarnava uma visão de revisionismo das teorias fundamentais que orientaram a Revolução Russa. Estas teorias fundamentais que se deram através do que chamamos de assalto ao Palácio de Inverno: uma insurreição revolucionária que racharia determinados setores das Forças Armadas e levaria o povo a assumir o poder e instauraria de cima para baixo um projeto socialista. Nenhuma das posições tinha uma análise adequada ou correta da realidade brasileira, porque as pretensões de luta armada naquele momento se chocavam com um desenvolvimento real que estava ocorrendo na sociedade brasileira; um desenvolvimento econômico que podia ser elitista, como efetivamente foi, mas que desencadeou no Brasil um processo de industrialização e de integração social, a partir inclusive das fábricas do $A B C$ e de outros investimentos que ocorreram em diversas regiões. $\mathrm{E}$ foi a partir destes processos que a sociedade brasileira começou a entrar na sociedade industrial moderna. $E$ as próprias reivindicações de liberdades políticas eram reivindicações que vinham da intelectualidade, das classes médias, de uma visão intelectual emancipatória mais construída em termos culturais do que vinculada aos desejos do país. Quando é que começam a aparecer estas ideias de liberdade? Esta luta pela liberdade? Na luta pelas Diretas [Já]. Aqui em Porto Alegre, por exemplo, houve um comício de cem mil pessoas. Eu falei neste comício: emergi da minha dupla camiseta e falei pelo PRC, inclusive. $E$ ninguém deu a mínima bola: "quem é esse PRC que ninguém conhece!? O Tarso, nosso advogado, está nesse PRC, o que quer dizer isso?!" São essas contradições que a gente vive como quadro político, intelectual, militante de classe média e que às vezes se descola muito da realidade. Então, veja, as reivindicações de liberdades democráticas no país começam a ter força quando entra em crise a economia e, o proletariado, em vez de se dirigir para o movimento revolucionário, ele se dirigiu para os contratos coletivos do trabalho, para as melhorias salariais, para uma relação mais concreta da sua vida cotidiana, para se colocar dentro deste processo de modernização capitalista do Brasil de uma maneira mais vantajosa para a classe trabalhadora. Foi quando surge o Lula.

\section{CRISTINA BUARQUE DE HOLLANDA:}

Para a decepção e frustração da militância que ao longo destes anos tinha se organizado a partir da ideia de movimento revolucionário.

\section{TARSO GENRO:}

Foi uma constatação envergonhada da esquerda marxista, que vai se adaptando paulatinamente. A teoria vai atrás da objetividade e vai mudando à medida em que a objetividade vai demonstrando o equívoco destas análises. Mas aí o surgimento do Lula como dirigente sindical com pretensão de se tornar um dirigente político atrai todos aqueles coletivos revolucionários porque viam nele a expressão de uma liderança operária que poderia ser uma espécie de aríete para o movimento revolucionário que estaria emergindo no grande $A B C$ e na grande São Paulo. Não foi nada disso que aconteceu; [essa] foi mais uma análise equivocada. O Lula era um homem do contrato coletivo, do diálogo sindical, de uma visão socialdemocrata avançada e um defensor irrestrito das liberdades democráticas, para as quais ele também passou a prestar atenção a partir da repressão das greves no $A B C$. Até então isso não era pauta do $A B C$; passou a ser quando a polícia, o aparato repressivo, começou a atacar o movimento 
ENTREVISTA COM TARSO GENRO

REVISTA ESTUDOS POLÍTICOS Vol. 10 | N.2 ISSN 2177-2851 Cristina Buarque de Hollanda

sindical, seja aquele mais ligado às organizações revolucionárias, seja o movimento sindical economicista e sindicalista que caracterizava a maioria da classe operária daquela região.

\section{CRISTINA BUARQUE DE HOLLANDA:}

Em algumas entrevistas do Lula na época, ele diz que anistia é coisa de elite, de estudante, que ele não tem nada a ver com isso, até ser afetado muito diretamente pela repressão com o fechamento do sindicato.

\section{TARSO GENRO:}

Eu participei de uma reunião com o Lula naquela época. Acho que o conheci em 78, não me lembro exatamente como foi. Foi um pouco antes de ele ser preso naquela greve. Ele foi visitar o Olívio Dutra em Porto Alegre e eu era advogado do sindicato dos bancários. O Olívio entrou na minha sala e disse: "vamos à minha sala que eu vou receber o Lula. Vamos prestar atenção nele, que este cara vai ser um líder político importante da classe trabalhadora." Eu fui lá conhecer o Lula. A gente ficou conversando e o Lula disse que uma lembrança importante que ele tinha do auge do regime militar era que carros de som passavam nos bairros operários daquela região do $A B C$ pedindo que os operários se apresentassem às fábricas porque estava sobrando emprego. Ele até nos disse: "não entendo porque vocês pedem revolução se os autofalantes estão chamando os operários para serem empregados!" Ele colocava isso de uma maneira muito simples, mas muito objetiva, que era um dado da conjuntura para o qual ninguém prestava muito atenção de maneira adequada, porque no geral se fazia uma análise marxista - que eu diria que é um pouco autoritária - sobre os trabalhadores a partir de uma visão mais ou menos assim: "olha, a classe operária tem potencial revolucionário. Aonde tem movimento operário tem possibilidade de organizar um processo insurrecional." O Brasil provou que esse era um equívoco muito grande, o que não desmonta, na minha opinião, a teoria marxista de exame da natureza do capitalismo e das formas de insurgência que a exploração pode causar, mas não [tal diagnóstico] era adequado ao tipo de movimento da economia e da política que nós tínhamos naquela época no Brasil. Porque quando estes projetos de reorganização da economia e do Estado começam a fazer água, a partir das sucessivas crises do petróleo, nós vamos verificar que a própria classe dominante, que governava o país numa aliança cívico-militar, não tinha solução para a crise. Aí começa a abertura e a democracia passa a ter efetivamente algum valor universal a partir daquele momento.

\section{CRISTINA BUARQUE DE HOLLANDA:}

Tarso, há pouco eu os debates no Congresso sobre a Lei de Anistia de 1979. E eu observei que ali parecia existir um mínimo denominador comum entre ARENA [Aliança Renovadora Nacional] e MDB, inclusive entre os "autênticos" do MDB. Ele [o mínimo denominador comum] era organizado em torno das ideias de conciliação, paz e esquecimento. Esquecimento era uma palavra muito requisitada naqueles debates. A premissa de fundo parecia ser a de que era importante fazer uma espécie de tábula rasa do passado para que se abrissem boas possibilidades para o futuro. Tudo que soasse destoante disso era tachado de revanchismo, tanto por emedebistas quanto por arenistas. Parecia que a disputa que estava em jogo era em torno de quem era o verdadeiro setor ou ator político disposto à paz e à conciliação. E quando eu fui ler os vários pareceres sobre a lei [de Anistia] que a Comissão Teotônio Vilela [encarregada de fazer relatoria do projeto de Lei de Anistia do governo] recebeu de várias 
entidades da sociedade civil, inclusive da $A B I$ [Associação Brasileira de Imprensa] e de várias sessões regionais da OAB [Ordem dos Advogados do Brasil], o tom dos pareceres não era discrepante daquele que eu identifiquei nos pareceres do Congresso. A partir daqui eu gostaria de lhe fazer duas perguntas. A primeira é se a sua memória sobre a transição é condizente com esta descrição que eu lhe fiz brevemente sobre as disposições politicas no Congresso e também nos setores mais organizados da sociedade na resistência ao regime? E a segunda pergunta é sobre como, na época, o senhor enxergava a Anistia e o processo político desencadeado por ela? Eu conheço a sua posição pública como Ministro da Justiça e logo mais nesta conversa eu gostaria de lhe ouvir sobre este outro capítulo de sua história. Mas a pergunta de agora é sobre a sua leitura sobre o processo de anistia naquele momento em que a campanha ganhou as ruas e acabou se tornando a grande alavanca para o retorno à democracia, associada a esse contexto de fundo fundamental que o senhor acabou de comentar, que foi a crise econômica e a emergência de lutas de perfil mais popular. Resumindo: a sua memória da anistia converge com essa ideia de um ambiente tomado pelo clamor por paz, conciliação, esquecimento e unidade familiar? Como que o senhor pessoalmente enxergava e se inseria nesse processo da anistia?

\section{TARSO GENRO:}

Acho que primeiro tem que haver uma indicação da configuração dos campos políticos no momento em que começa a abertura lenta e gradual do general [Ernesto] Geisel [1974-1979]. Alguns momentos são fundamentais, paradigmáticos desse processo. Um desses momentos é quando o general Geisel demite o comandante do Terceiro Exército em função do assassinato do Vladimir Herzogi. E, depois, tem outro assassinato que leva o general Geisel à desmontagem do aparato da Operação Bandeirantes. Naquele momento, houve uma disputa interna nas Forças Armadas, uma ala orientada pelo general Golbery [do Couto e Silva] e outra pelo então Ministro da Guerra, Sílvio Frota. Tem um momento em que o irmão do general Geisel, o general Orlando Geisel, disse para o seu irmão a respeito do comandante do Terceiro Exército: "demitao ou humilhação. Se não houver uma atitude forte, a extrema-direita do Exército vai te derrubar." O Presidente Geisel demite e vai a São Paulo. E quando ele chega lá, consegue coordenar os comandos todos para recebê-lo de uma maneira responsável e subordinada ao Presidente da República e, portanto, Comandante Supremo das Forças Armadas. Naquele momento, esta ala da anistia começa a se firmar. É estabelecido um compromisso com o general Figueiredo, que estava no SNI [Serviço Nacional de Inteligência] e sabia que era necessário fazer anistia. O governo estava perdendo rapidamente a sustentabilidade do grande empresariado, estava perdendo os setores da classe média em função da crise econômica no país e as movimentações operárias começavam a fluir. Algumas delas apareciam inclusive com direções revolucionárias, de esquerda, embora a maioria fosse inspirada no sindicalismo tradicional, num sindicalismo economicista.

\section{CRISTINA BUARQUE DE HOLLANDA:}

O senhor diria que as denúncias de violações de direitos humanos neste contexto também compuseram este elenco de motivos da fragilização do governo? 
ENTREVISTA COM TARSO GENRO

REVISTA ESTUDOS POLÍTICOS Vol. 10 | N.2 ISSN 2177-2851 Cristina Buarque de Hollanda

\section{TARSO GENRO:}

Foram relevantes porque a crise econômica, as dificuldades de desenvolvimento econômico do país e o empobrecimento do Estado brasileiro para prestações sociais estava aumentando, aí o desejo de liberdade se torna um elemento da política; então, as duas coisas convergem. E, do lado da oposição, tinha uma hegemonia centrada nos senadores, deputados e nas lideranças regionais que tinham compatibilizado a sobrevivência do MDB com o regime militar, nós dizíamos. Naquela época, muita gente vestia camisa dupla, vestia a camisa do MDB eventualmente para lançar algum candidato, para apoiar algum movimento do parlamento. A gente dizia que o MDB era uma oposição consentida e havia denúncias no exterior de que 0 MDB se tratava de um partido fantoche. Teve um determinado momento [1964-1970] em que a presidência do MDB era do quadro, um general, que era um general da direita, o Oscar Passos, que estava lá para gerir o MDB como oposição composta, aconselhada, que se tornou hegemônica dentro do MDB. Então, essa negociação da ditadura militar, dos que queriam a abertura dentro do regime e dos que aceitavam qualquer tipo de abertura dentro do MDB, foi se estreitando até chegar a uma relação de compromisso. Essa relação de compromisso é estabelecida a partir da Lei de Anistia e é importante compreender que, depois de aprovada, ela sofreu inúmeras modificações e decisões judiciais que foram colocando-a num patamar histórico e democrático mais razoável, porque a Lei de Anistia originária, na verdade, devolvia os direitos políticos daquelas pessoas que tinham sido cassadas, que eram pessoas que estavam na legalidade sem nenhum problema de relação com a clandestinidade, sem nenhuma luta mais radical ou mais ousada. $\mathrm{E}$, sobretudo, dava anistia aos donos do regime: anistiava os donos do regime.

\section{CRISTINA BUARQUE DE HOLLANDA:}

Mas anistiava de uma maneira indireta, com o recurso do "crime conexo".

\section{TARSO GENRO:}

O elemento do "crime conexo" foi colocado a partir de uma exigência desses quadros militares que tinham participado daqueles processos mais violentos. Quando eu era Ministro da Justiça e a gente falava em não aplicar a Lei de Anistia para torturadores, o que a gente dizia? Eu dizia: "nós não estamos falando aqui de que os ex-Ministros das Forças Armadas e os quadros das Forças Armadas não têm que receber anistia porque eles não estão sendo processados. Nós estamos dizendo que a Lei de Anistia não pode ser aplicada para quem não adotou a legalidade do regime militar, porque o regime militar brasileiro, ao contrário do argentino, não autorizava a execução de pessoas. Em nenhum momento, o Estado brasileiro legalizou a tortura, pelo contrário, era negada a tortura". Então, nós dizíamos: "a Lei de Anistia não abrange crimes contra a humanidade." Não se tratava de crimes conexos. Nós perdemos esta discussão quando foi feita mais tardeii. A Lei de Anistia foi um produto de arranjo de conciliação, que, infelizmente, com a morte do Presidente Tancredo Neves, consagrou como Presidente da República alguém que vinha do regime, da ARENA, o José Sarney, que passou a ser presidente de honra do PMDB. E isso é muito característico da sociedade brasileira. Eu acho que historicamente não foi ruim, porque disso decorreu a Constituição de 1988 e não se sabe exatamente o que aconteceria no Brasil se a ala de extrema-direita do Exército tivesse ganhado e transformasse o Brasil num arremedo brutal do que foi a Argentina, que em quatro ano de 
ENTREVISTA COM TARSO GENRO

REVISTA ESTUDOS POLÍTICOS Vol. 10 | N.2 ISSN 2177-2851 Cristina Buarque de Hollanda

governo fizeram assassinatos em massa. Lá tiveram que prestar contas. Essa conciliação que ocorreu na transição brasileira, que é muito característica da nossa história, a "conciliação das elites", tem até uma categoria de metodologia da história que analisa esse momento de crise com esta formulação - é um processo de "conciliação das elites", que refrearam e organizaram a transição de um modo a interessar mais às classes dominantes, mas devolveram as liberdades políticas. De um lado, vivemos um processo de conciliação política. Mas, do outro, o Brasil não entrou numa guerra civil. Isso não quer dizer que não tenha tido um lado justo e outro injusto; não é isso. Mas evitou-se uma guerra civil. Seria uma guerra civil que desembocaria num processo histórico já de refluxo do movimento comunista, da socialdemocracia, do movimento socialista, dos valores democráticos da igualdade e da solidariedade e, portanto, poderia posteriormente levar o Brasil a um brutal isolamento se tivesse havido uma vitória do campo revolucionário democrático naquele momento. É difícil a gente dizer o que seria melhor. O que seria melhor seria uma Constituinte livre e soberana originária, que não tivesse essa amarra de uma Constituinte que foi derivada, na qual foi usada o próprio Congresso Nacional, e, portanto, pessoas que não estavam destinadas especialmente para produzir, discutir e votar uma Constituição. Mas esse é o processo que nós temos. Agora a segunda questão, no Ministério da Justiça, eu reorganizo completamente o Ministério da Justiça. O Lula me dá pessoal, recursos e todas as condições para reorganizar. Nós cadastramos os processos, estruturamos as comissões de julgamento, fizemos as Caravanas da Anistia e fomos anistiar os camponeses que fizeram a luta armada no Pará. Eu fui levado por um avião da FAB para lá. Então, nós já tínhamos uma institucionalidade respeitosa em que as questões de Estado eram tratadas dentro do processo constitucional, de uma maneira respeitosa e ordinária. Naquele momento, nós mudamos o conceito de anistia. O Paulo Abrão era o meu secretário da Comissão de Anistia e foi quem organizou todo este sistema. Nós fizemos também um trabalho jurídico e cultural para mudar o conceito de anistia: tradicionalmente, em toda a literatura jurídica, a anistia é considerada um perdão - os vencedores perdoam os derrotados. E nós dissemos que a partir de agora a anistia não é mais um perdão aos derrotados, é um pedido de desculpas que o Estado faz para aquelas pessoas que foram injustiçadas por um regime deposto. Agora, imagina que isso daí teve um reflexo bastante tenso naquele momento em relação aos setores das Forças Armadas, aos setores seus mais direitistas, e gerou um debate muito forte na academia, nos jornais e assim por diante. Então, essa mudança conceitual a respeito da anistia nos permitiu fazer com que a Comissão de Anistia funcionasse com dignidade, que as pessoas fossem indenizadas dentro do possível e de acordo com as provas de perseguição que trouxessem junto à Comissão de Anistia, inclusive levando em consideração a dificuldade de obtenção de provas que existia. Esta mudança conceitual se tornou uma mudança com influência internacional, porque ela violou aquele conceito elitista de que quem faz a anistia perdoa os criminosos. O mínimo que se pode dizer para ter uma anistia saudável é o seguinte: "não há o que perdoar porque vocês não são criminosos, nós temos que respeitar os direitos de vocês." Nós demos um passo adiante porque nós dissemos que o Estado devia pedir desculpas. Então, em cada sessão da Comissão de Anistia, em cada caravana que o Paulo Abrão coordenava - e que agora está fazendo um trabalho maravilhoso na OEA [Organização dos Estados Americanos] - nós fazíamos este discurso. Foi uma situação difícil, porque havia muito descontentamento da esfera militar, mas sempre que podíamos também conversávamos com os militares e lhes dizíamos de maneira 
didática e respeitosa que nós não queríamos fazer depreciação de ninguém, mas que a partir do Estado brasileiro tínhamos que ter um novo olhar sobre o sofrimento dessas famílias: pais desaparecidos, crianças desaparecidas, mulheres e homens torturados, mulheres violadas, jovens assassinados. É claro que a repressão, a violência e a morte na Argentina e no Uruguai foram maiores do que aqui. Mas a partir da visão de que a violação dos direitos de um indivíduo é a violação do universo humano, a sua dimensão torna-se imensurável, embora sejam violências diferentes e com reflexos diferentes sobre o conjunto da população sobre o qual elas incidem.

\section{CRISTINA BUARQUE DE HOLLANDA:}

Esse momento da sua gestão do Ministério da Justiça, quando o Paulo Abrão assume a Comissão de Anistia, claramente marcou uma inflexão no tratamento de Estado aos crimes da ditadura. Foi algo muito impactante porque a abordagem que vocês propuseram era ousada em relação inclusive aos partidos de esquerda. Mesmo no PT e no PDT, por exemplo, à época da transição, esse tema da violência da ditadura não ressoou. Me parece que durante a campanha da anistia as denúncias de violações dos direitos humanos alcançaram algum protagonismo na cena pública, mas, uma vez que a lei de 79 foi promulgada, este assunto vai para o pano de fundo da cena política. Brizola dizia repetidamente que havia feridas que não deveriam ser tocadas. E tampouco o Lula tinha sensibilidade para o assunto. Quando o senhor esteve à frente do Ministério da Justiça, pela primeira vez o assunto foi pautado como questão de direito público, e não de direito privado, que parecia ser o enquadramento principal até então. A minha pergunta é: para além do seu protagonismo e do Paulo Abrão naquele momento, quais foram as condições mais gerais para que isso ocorresse? Que outros atores e outras correlações de força foram importantes para que fosse possível esta virada? O que mudou depois de tanto tempo da transição?

\section{TARSO GENRO:}

A universidade e a academia que possuíam arquivos e trabalhos publicados sobre esses atores e sobre a repressão, a existência da Secretaria caracterizada como Ministério dos Direitos Humanos, dirigida pelo Paulo Vannuchi, que foi uma figura extraordinária neste processo e foi vítima, inclusive. Uma pessoa com um equilíbrio emocional e político espetacular para manter a tranquilidade porque quando muito jovem ele foi brutalmente torturado pela Operação Bandeirantes. O Paulo Abrão e o apoio de algumas figuras emblemáticas da sociedade brasileira, ora da imprensa, ora da academia, ora do mundo artístico, que compreenderam a questão da anistia como um marco civilizatório para o país. Uma República que não se acerta com o seu passado não vai compreender o que tem de fazer em seu futuro. Era isso que a gente colocava de maneira respeitosa para os militares; nós nunca dissemos que de um lado tinham os anjinhos que não cometeram nenhum mal e nenhuma injustiça - eventualmente atacando algumas pessoas que eram simplesmente funcionárias do regime militar - e que de outro lado estavam os bandidos. Não se tratava disso. Tratava-se do enfrentamento dos operadores de um regime determinado, de um lado, e dos operadores políticos de uma rebelião contra aquele regime, do outro. Não é possível dizer que todos tinham razão: alguém não tinha razão! Mas isso deve ser separado dos indivíduos singulares que estão envolvidos no contencioso para que não se passe a imagem - que até certo ponto os militares conseguiram passar - de que era revanchismo. Não, não era revanchismo. Uma vez eu tive uma conversa 
com um militar da ativa e conversávamos de maneira civilizada sobre este assunto e ele me disse o seguinte: "se vocês vão aplicar a punição para o que vocês chamam de torturadores do regime militar, nós também temos que aplicar as punições para as pessoas que estavam do outro lado." Ao que eu respondi para ele: "as pessoas que estavam do outro lado já foram presas, a maioria delas torturadas, muitas delas assassinadas e tiveram suas vidas destruídas. Eles já foram responsabilizados, se é que a questão é essa, de cunho punitivo, eles já foram punidos. Agora, aquelas pessoas que em vez de pegarem os presos e levarem para uma estrutura institucional do Estado para que ele fosse investigado mesmo dentro das leis do regime militar, não fez isso. Levou o cidadão para um aparato paralelo e clandestino da ditadura, então este agente cometeu um crime comum: sequestro, depois tortura ou morte". Nós fomos tratando de maneira racional, porque esta é uma ferida que permanece aberta no país até hoje. Nós elegemos um Presidente da República que defendeu publicamente a tortura, que homenageia uma pessoa que é apontada como o maior torturador da República brasileiraiii! E isso foi assimilado e aceito por uma boa parte da população. Uma população alienada, brutalizada. $E$ nós estamos agora num momento em que temos que enfrentar novamente este debate. Agora não se trata mais de dizer quem tem que ser punido, mas de bloquear a emergência do fascismo aqui no Brasil, que tem o seu lado, os seus grupos de comando de pessoas que defendem a eliminação do seu adversário, a morte, a política necrófila, o deboche da ciência, a vontade sanguinária de eliminar os adversários, como já foi exposta por alguns líderes que hoje dirigem o nosso país. Os acúmulos de conquista da democracia não se sobrepõem uns aos outros de modo a criar uma nova situação democrática. Eles podem ser cumulativos, mas de repente eles podem desandar em função de uma crise econômica brutal que levam pessoas a situações extremas de desespero e de deformação psíquica, inclusive como está ocorrendo hoje no Brasil.

\section{CRISTINA BUARQUE DE HOLLANDA:}

Esse assunto contemporâneo me interessa muitíssimo, mas vou pedir licença para de novo fazer uma marcha ré no tempo, porque demos um salto na sua biografia: fomos do momento da anistia à sua chegada ao Ministério da Justiça. Eu queria perguntar se antes da sua chegada ao Ministério da Justiça o senhor teve algum tipo de envolvimento com essa pauta dos crimes da ditadura. Eu estou estudando boletins que foram produzidos por associações de anistiados que começaram a se formar em princípios dos anos oitenta e, por acaso, me deparei com a menção a um parecer seu sobre a situação dos não-anistiadosiv .

\section{TARSO GENRO:}

Da Petrobrás.

\section{CRISTINA BUARQUE DE HOLLANDA:}

Isso. A ADNAM fazia uma espécie de clipping de todas as notícias que saíam e eram relativas à anistia. Eu fiquei curiosa em saber que tipo de ação o senhor teve neste longo meio tempo entre o processo da campanha da anistia e a sua chegada ao Ministério da Justiça? De que maneira esta pauta encontrou a sua carreira pública e em que momento? 
ENTREVISTA COM TARSO GENRO

REVISTA ESTUDOS POLÍTICOS Vol. 10 | N.2 ISSN 2177-2851 Cristina Buarque de Hollanda

\section{TARSO GENRO:}

Eu como advogado atuei intensamente representando pessoas que buscavam anistia ou pessoas que sofreram algum tipo de perseguição no seu passado político. Eu fui vice-presidente do Instituto dos Advogados do Rio Grande do Sul e lá houve uma partilha de responsabilidade em que o presidente tratava de certos assuntos, cargo que era ocupado por eminentes juristas daquela época, e eu organizava o Comitê Unitário pela Constituinte. E por dentro deste comitê passava um conjunto de organizações políticas legais e outras mais discretas e organizações da sociedade civil que lutavam pela anistia. Agora, a pauta da anistia torna-se importante a partir da Lei de Anistia [de 1979]. Até ali as movimentações pró-anistia eram moleculares. E eram movimentações voltadas para casos concretos de grupos específicos, de empresas estatais, de organizações da sociedade civil que defendiam determinados direitos, que teriam consequências na vida das pessoas, como a devolução de direitos políticos. Ela passa a ser uma pauta estrutural da política do Brasil mais tarde, quando grande parte da esquerda e do campo democrático em geral se dá conta de que a Lei da Anistia foi uma lei feita predominantemente para anistiar os crimes da ditadura e atender parcialmente determinados setores da oposição, trazendo para a legalidade aquelas lideranças tradicionais. Depois, a construção jurídica que foi feita e as sucessivas regulações transformaram esta abertura para a anistia numa anistia que realmente se tornou importante e que abrangeu, eu diria, pelo menos $90 \%$ das pessoas que foram perseguidas, humilhadas e eventualmente muito prejudicadas pela ditadura militar. $\mathrm{E}$ a participação da esquerda no ponto em que eu me situava não tinha relação imediata, a não ser a participação nos Comitês pela Anistia, associações de direitos humanos, a realização de manifestações dentro da universidade, que eram coisas muito pontuais e que não tinham adesão maciça. Você ia à assembleia popular de um bairro, por exemplo, e dizia que estavam propondo anistia. As pessoas perguntavam o que era a anistia: "o Brizola vai voltar? Vão deixar o Jango ser Presidente de novo?" Havia uma separação entre a vida social popular - que se dava nas grandes periferias das cidades, nos grandes movimentos sociais em defesa de saneamento, de mais escolas e de transporte coletivo - e a pauta política. Esta pauta política passa a ser importante quando o conceito de anistia da proposta do Figueiredo começa a adquirir um certo vigor. Mas sempre tratado de uma maneira peculiar, segregada. Vou dar um exemplo concreto da minha experiência. Eu chamo ao Ministério da Justiça juristas, inclusive o Paulinho Vannuchi estava comigo, para fazermos uma sessão pública sobre os efeitos da Lei de Anistiav. Aí convido um advogado de São Paulo que defendia a aplicação da Lei de Anistia aos torturadores e era uma pessoa civilizada que aceitou o debate. E tinha um outro advogado, um outro jurista que dizia que não devia se aplicar. Nessa discussão, eu encerro esse debate, que foi muito importante, com todo o pessoal da Globo colocando em pauta no Jornal das oito. E eu encerro dizendo que a minha posição como Ministro da Justiça é que a Lei da Anistia não pode ser aplicada sobre torturadores, seja civil seja militares porque crimes contra a humanidade não devem ser anistiados. Eu disse que o Ministério ia se organizar para realizar uma discussão nacional. Aí foi uma coisa que causou constrangimento dentro do governo: setores do governo começaram a me pressionar para que eu tirasse isso da pauta, setores do PMDB se manifestaram publicamente contrários à minha posição, nos acusando de querer remexer em coisas do passado. Eu fui atacado por senadores do PMDB. Naquela oportunidade, o Pedro Simon que era uma pessoa com quem eu tinha relações de amizade. Ele me telefona e diz: "Tarso, é absolutamente inapropriado e fora de tempo você colocar essa questão. Você não 
ENTREVISTA COM TARSO GENRO

REVISTA ESTUDOS POLÍTICOS Vol. 10 | N.2 ISSN 2177-2851 Cristina Buarque de Hollanda

devia ter colocado isso agora." E eu lhe disse: "só me diz então quando é que vai ser o tempo. Nós estamos numa transição infinita, num regime democrático, a Constituição funcionando e uma anistia completamente atrasada em relação aos tempos que nós estamos vivendo no Brasil. Quando é que vai ser o tempo correto para tratar disso?!" E ele me disse: "acho que você tem mesmo razão, mas eu acho impróprio..." Havia um grande temor do que aquilo podia representar. E o Simon foi um opositor do regime militar, ele defendia um regime democrático, tinha um diálogo respeitoso com os quadros militares, mas sempre teve uma abertura favorável à Constituinte. Esse receio é uma coisa entranhada na sociedade brasileira; está presente na cultura política. Tem também alguns erros de propaganda que o nosso pessoal cometeu, eu diria: na primeira eleição em que o PT participou, ainda estava vigente a Lei Falcão. E aparecia o pessoal que era originário da ARENA e do MDB de gravata e terno. E os nossos candidatos era um pessoal barbudo, ex guerrilheiros da luta armada. E os demais ficavam perplexos com esta forma imprópria de se apresentar politicamente, inclusive supondo que tinha também uma romantização da revolução nas amplas massas que iam votar. Aí este pessoal fazia 40 ou 50 votos e eles tinham que compreender que tinham de apresentar uma linguagem política diferente para ser exercitada dentro da democracia. Aí foi um aprendizado que o PT teve de maneira muito consistente até chegar à Presidência da República.

\section{CRISTINA BUARQUE DE HOLLANDA:}

Quando o senhor chega ao Ministério da Justiça, a Comissão de Anistia era um problema. Ela era estigmatizada por setores da direita e algumas indenizações atribuídas, de valores muito altos, foram objeto de um certo escândalo público. Eu queria saber a sua opinião sobre a lei de criação da Comissão de Anistia? Se o senhor tivesse tido poderes de retocar a lei, que tipo de retoque teria feito?

\section{TARSO GENRO:}

Acho que dentro da correlação de forças existentes naquele momento, dentro do próprio governo do Estado brasileiro, ela foi o limite. Ela não tratou de maneira adequada os desiguais. $\mathrm{O}$ que eu quero dizer com isso? Eu quero dizer, por exemplo, que quem era um assalariado de salário mínimo teve indenização com base naquele salário mínimo e a pessoa que ganhava 50 salários mínimos teve indenização a partir dos 50 salários que recebia. Não é adequado. Os desiguais têm de ser tratados de forma desigual para serem tratados igualmente perante o Estado. Mas isto é um conceito jurídico de alta complexidade, que não foi apanhado pela Lei de Anistia. O meu caso concreto: eu estive impedido de exercer a minha profissão durante quase dois anos e tive que sair do país. Eu tecnicamente estaria abrangido pela Lei de Anistia - eu poderia ter pedido indenização por este ano que fiquei fora, como teve centenas de milhares de pessoas em situação semelhante fizeram. E fizeram por necessidade. Mas eu diria que talvez algumas pessoas tenham feito este pedido de maneira não necessária. Eu não fiz esse pedido porque saí do país e fui convidado para lecionar no Uruguai, eu estava me mantendo e, como eu era sócio do escritório do meu pai, ele me mandava um pequeno percentual do nosso escritório que me permitiu sobreviver com dignidade. Então eu entendi que não seria adequado pedir uma indenização porque realmente eu não passei nenhum sacrifício e eu passei por isto em função da escolha que fiz na minha vida como militante. A ampla maioria das pessoas que recorreram à Comissão de Anistia o fizeram de maneira necessária e absolutamente justa. A ampla maioria. Se eu tivesse que dar um percentual, eu diria que $95 \%$. Mas aí, nos outros 5\%, 
a direita se apega a determinados exemplos para manchar todo o processo como se ele fosse um socorro para quem não tinha necessidade. Teve polêmica pública entre jornalistas, em que um acusou o outro de ter um benefício que seria abusivo. São coisas que ocorrem no processo. Mas em regra, processualmente, a anistia brasileira colocou muitas coisas boas no seu devido lugar, com alguns erros e equívocos que ocorrem e que, vamos dizer, são incontornáveis num processo dessa complexidade. Eu não me lembro o que poderia ser feito em adição a esta lei, porque ela foi sendo gradualmente corrigida e absorvida na sociedade brasileira como um todo.

\section{CRISTINA BUARQUE DE HOLLANDA:}

Tarso, eu acho curioso que tanto a lei de criação da Comissão Especial de Mortos e Desaparecidos como a lei de criação da Comissão de Anistia não falem em direitos humanos. É surpreendente que o vocabulário dos direitos humanos só se encontre com o tema dos crimes da ditadura, em forma de lei, na criação da CNV [Comissão Nacional da Verdade].

\section{TARSO GENRO:}

A partir da criação da Secretaria dos Direitos Humanos isso se tornou uma pauta.

\section{CRISTINA BUARQUE DE HOLLANDA:}

Ah, sim, é verdade. Ainda sobre a Comissão de Anistia, eu queria Ihe fazer uma última pergunta. Na militância de denúncia da ditadura, a gente enxerga claramente a organização de dois grupos. Um grupo que reúne familiares de mortos e desaparecidos e outro que se organiza em torno dos não anistiados e também dos anistiados que querem melhoramentos de sua condição. Havia - e há - sobreposições entre os dois, claro, mas as linhas de distinção são bem nítidas também. Em muitas entrevistas que eu fiz, eu percebi relações de um certo antagonismo ou mal-estar entre esses grupos. Eu queria Ihe perguntar se isso teve alguma repercussão no seu trabalho no Ministério, se trouxe alguma dificuldade?

\section{TARSO GENRO:}

Sim, tem um ressentimento que foi bastante evidente naquele período, vinculados aos familiares dos desaparecidos, principalmente. As pessoas que até hoje não sabem onde estão seus filhos, irmãos, familiares mais próximos porque eles simplesmente desapareceram. E para que se tivesse uma resposta para isso, seria necessário que partisse de dentro das Forças Armadas, porque não havia possibilidade de que estes documentos fossem requisitados na íntegra, porque essa instituição fez uma colocação histórica com relação a isso logo no começo da abertura, dizendo que estes documentos foram eliminados. E talvez muitos deles tenham sido eliminados mesmo ou então escondidos em algum lugar. $E$ isso tornava difícil que um juiz ou que o próprio Presidente da República determinasse a apresentação de documentos que tecnicamente não existiam mais naquele momento. Eu acho que isso não terá fim. Porque, se em algum momento estes documentos existiam, certamente foram eliminados. Em algumas oportunidades, em função do meu cargo de Ministro da Justiça, eu tive contato com pessoas que foram responsáveis pela repressão. Uma vez eu fui procurado dentro do Ministério da Justiça pelo Curió [Sebastião Curió Rodrigues de Moura, o Major Curió]. Acho que é a primeira vez que estou relatando publicamente esta situação. Ele entrou em contato com a minha assessoria e disse que queria falar comigo. Era o momento em que estava em discussão a questão dos corpos lá na região da guerrilha do PC do B. E eu disse que o receberia. Ele não 
queria que fosse divulgado porque ele tinha medo de ser sentenciado na clandestinidade dos grupos que permaneciam organizados protegendo as barbáries que foram feitas. Segundo ele, seu desejo era de uma reunião discreta comigo. Aí, eu o recebi no Ministério da Justiça e ele me disse o seguinte: "eu sei que o senhor não vai acreditar; eu nunca torturei ninguém, nunca matei ninguém covardemente, mas matei muita gente na guerrilha, na batalha." Eu não acreditei nele, mas não estava ali para acreditar ou não; queria saber qual informação que ele ia me trazer. Aí ele trouxe num papel datilografado, sem timbre, obviamente, uma relação de pessoas que tinham participado da guerrilha [do Araguaia] como bate-paus do Exército. Estes indivíduos foram forçados a isso: foram tirados de sua rotina como camponeses ou de pessoas que viviam do extrativismo florestal e foram colocadas a serviço do Exército para caçar aquela guerrilha elementar do PC do B, que estava lá com alguns jovens tentando organizar uma movimentação guerrilheira. Isso ajudou a Comissão de Anistia, para que fosse verificado se alguns deles estavam pedindo algum valor indenizatório por terem sido utilizados pelo Estado brasileiro para fazer aquele serviço na floresta para caçar os guerrilheiros. Isso foi levado de uma forma absolutamente formal, depois nós fomos até Xambioiá e fizemos uma assembleia pública de anistia onde foram envolvidas determinadas pessoas que também estavam naquela lista. Nunca mais tive notícias daquela situação. Acho que deve ter sido uma demanda dos próprios camponeses, que ficaram a serviço do Exército naquele momento, através do Curió (que certamente era um dos chefes da movimentação da repressão) para obter do Estado brasileiro alguma reparação. Depois houve também junto à $O A B$ um movimento de soldados que participaram da repressão à guerrilha e depois foram desligados do Exército e que diziam que tinham traumas psicológicos brutais por aquilo que foram obrigados a fazer. Eles diziam terem sido obrigados pelo Estado a praticar certo tipo de violência sobre os guerrilheiros. Então a $\mathrm{OAB}$ fez uma representação junto ao Ministério Público. Parece inclusive que eles preferiram o caminho da Justiça para pedir esta indenização. Tem coisas que acontecem nesta transição que nunca vão ser descobertas, nunca vão ficar absolutamente claras. Agora, a resposta geral a essa pergunta é que sim, no geral, o processo de anistia valeu a pena. Sim, houve uma manifestação do regime militar que, para proteger os seus, teve de também abrir aos seus oponentes a possibilidade de anistia. E as nossas circunstâncias democráticas permitiram que esta abertura se transformasse numa porta muito larga para fazer muitas reparações importantes para estas famílias que foram atingidas. E as limitações do processo de anistia são limitações que estão nos direitos humanos até hoje no Brasil. São limitações que permanecem; tanto é verdade que elas ainda podem ser expressas publicamente como bandeiras de pessoas que depois são eleitas até para a Presidência da República.

\section{CRISTINA BUARQUE DE HOLLANDA:}

O senhor poderia comentar, no seu período no Ministério da Justiça, sobre as suas relações com o [Paulo] Vannuchi e com o [Nelson] Jobim; as afinidades e dificuldades que encontrou com cada um deles.

\section{TARSO GENRO:}

Havia uma afinidade estrutural entre o meu posicionamento e o do Vannuchi. E havia, sim, diferenças muito grandes entre a minha visão e o posicionamento do Jobim. Ele entendia que a legislação de anistia devia ser empregada de maneira indeterminada, para todos os participantes da resistência e da repressão, porque, para ele, assim a anistia não seria 
ideológica. Como se as pessoas que executaram aqueles atos não estivessem determinadas, não estivessem mandatadas por alguma vocação política mais ou menos democrática. Eu tive, sim, impasses com o Jobim e tive inclusive conversas com o Presidente Lula sobre isso em determinados momentos. Tanto é verdade que o Presidente Lula me pediu para retirar este debate de dentro do Ministério da Justiça porque ele disse que estava sendo muito problemático. Ele disse que eu fizesse esse debate nas universidades, nas assembleias legislativas, na sociedade. Segundo o Presidente, se o debate continuasse dentro do Ministério da Justiça, poderia parecer que este desejava um confronto com as Forças Armadas, o que é uma posição absolutamente saudável de Presidente da República, que tem que cuidar de todos os aspectos do funcionamento do Estado, principalmente de um Estado que estava recentemente emergindo para uma legalidade democrática, que admitia um governo socialdemocrata como o do Lula. A partir dali eu permaneci com os debates da anistia, desenvolvemos as caravanas [da anistia], mas retiramos de dentro do Ministério da Justiça o que eu fiz, a pedido do Presidente da República. Isso não prejudicou o trabalho que nós vínhamos fazendo e pacificou internamente o front. Mas em relação ao Jobim, que é uma pessoa pela qual eu tenho enorme respeito, eu sou amigo do Jobim desde a adolescência, em Santa Maria. É uma pessoa de que gosto e respeito e acho que ele tem o mesmo respeito por mim. Mas sempre tivemos determinados debates políticos nos quais buscávamos compor sempre na melhor possibilidade. O Jobim é uma pessoa que é muito mais próxima do PSDB e do Fernando Henrique do que do nosso campo, mas ele foi um Ministro muito fiel, respeitado no governo Lula e Dilma, com todas as características que ele tem. E eu permaneço amigo dele até hoje, o que não esconde as nossas divergências, dentre elas, sobre o que é a questão democrática, a importância que tem a utopia socialista na construção da democracia e qual é o novo significado socialdemocrata hoje, em esfera global. Nós temos divergências sobre isso. Como eu digo para ele: eu o vejo como um conservador republicano e democrático. E isso é muito importante num país atrasado politicamente como o nosso, em que até o [João] Dória é visto como comunista por muitos setores da sociedade.

\section{CRISTINA BUARQUE DE HOLLANDA:}

Tarso, uma curiosidade: a inclusão do eixo "memória e verdade" no PNDH-3 [Plano Nacional de Direitos Humanos 3] foi uma proposta do governo ou uma articulação dos movimentos de familiares?

\section{TARSO GENRO:}

Pelo que eu tenho memória, foi uma iniciativa que teve base na ação política do Paulo Vannuchi. Foi aí que isso se cristalizou como mais um degrau da ação política dos nossos governos. E evidentemente que todas as questões que versam sobre direitos humanos têm algum tipo de reflexo em todos os Ministérios, e particularmente no Ministério da Justiça. Mas esta é uma área dos direitos humanos propriamente ditos em que não tivemos problemas com os órgãos do governo federal. A Polícia Federal está há muito tempo afastada de qualquer ato de violência na produção de seus inquéritos. Pode ocorrer excepcionalmente aqui e ali, como ocorre em todos os países do mundo, mas é uma polícia que está estruturada de maneira bastante republicana e que deve ser considerada uma reserva de valor hoje, desde a Constituição de 88 e que deve ser tratada de maneira adequada e respeitosa. Ela pode inclusive ter um papel importante na retomada do projeto democrático de 88 a partir de agora. 
ENTREVISTA COM TARSO GENRO

REVISTA ESTUDOS POLÍTICOS Vol. 10 | N.2 ISSN 2177-2851 Cristina Buarque de Hollanda

\section{CRISTINA BUARQUE DE HOLLANDA:}

Eu recentemente vi um evento que ocorreu no Instituto Fernando Henrique, em que o general Sérgio Etchegoyen avalia que o governo Dilma e a Comissão da Verdade teriam sido uma espécie de ponto de ruptura com os militares ${ }^{\mathrm{vi}}$. Eu queria saber se o senhor concorda com isso. A Comissão Nacional da Verdade teve ao fim e ao cabo algum efeito, digamos, disruptivo sobre o nosso cenário político?.

\section{TARSO GENRO:}

O general Etchegoyen é um intelectual das Forças Armadas. Ele é um elemento de referência política dentro das Forças Armadas. Ele é uma pessoa que conhece as questões nacionais e conhece as questões das Forças Armadas. Eu até achei que ele fosse permanecer no núcleo político das Forças Armadas para tentar dar uma travada nas loucuras e na demência do Presidente atual. Que eu saiba isso não aconteceu. Essa formulação do general Etchegoyen é, na minha opinião, injusta. Ele verbaliza uma parte das Forças Armadas, uma parte significativa que não quer ouvir nada a respeito do passado das Forças Armadas e do regime militar. Esses militares dizem: "vocês estão ofendendo as Forças Armadas e eu não tenho nada a ver com isso. Naquela época eu estava na academia, era tenente etc. E vocês, da esquerda, tratam as Forças Armadas como se ela fosse uma organização de violência premeditada contra o povo", etc. Isso é compreensível dentro de uma cultura corporativa que existe não somente nas Forças Armadas, mas em todos os órgãos de funções essenciais dentro do Estado. Um Ministro do Supremo, por mais jurista e aberto que seja, se ele fala publicamente sobre o Supremo Tribunal Federal, dirá que todos lá dentro são comprometidos com a Constituição. Se você conversa com um quadro político de partido do Congresso Nacional, ele dirá que lá é o foco ou elemento essencial da democracia. Pode ser e pode não ser, dependendo da maioria que vai se formar num determinado momento histórico. Eu acho que o general Etchegoyen elencou fatores baseado nesta cultura corporativa. Eu acho que ele sabe que não foi isso que determinou a separação. O fato é que existe majoritariamente nas Forças Armadas - e nem estou dizendo que não seja natural que isso exista - um projeto de preservação da sua própria memória, mesmo dentro do regime militar. As Forças Armadas na fundação da República ou no tenentismo são diferentes daquelas que estiveram presentes no regime militar: elas são diferentes em suas circunstâncias históricas. A ideologia e a cultura política que movem as Forças Armadas nesses momentos históricos são diferentes entre si. Mas acho que os militares não fazem esta separação e exigem que aqueles que estão na esfera política e na esfera do Estado tenham o mesmo pensamento que eles próprios. Então eu acho que o general Etchegoyen está completamente equivocado a respeito disso, mas ele faz uma homenagem a esse espírito majoritário que existe dentro das nossas Forças Armadas.

\section{CRISTINA BUARQUE DE HOLLANDA:}

Tarso, eu lhe agradeço imensamente por essa entrevista.

\section{TARSO GENRO:}

Perfeito. Obrigada e boa sorte. Foi um prazer conversar contigo. 
(Recebido para publicação em outubro de 2019)

(Reapresentado em setembro de 2019)

(Aprovado para publicação em dezembro de 2019)

\section{Cite esta entrevista}

GENRO, Tarso, 2019. Entrevista com Tarso Genro, conduzida por Cristina Buarque de Hollanda. Revista Estudos Políticos: a publicação semestral do Laboratório de Estudos Hum(e)anos (UFF).Rio de Janeiro, Vol.10 |N.2, pp. 179-197, dezembro de 2019.

\section{Notas}

1. Tarso Genso se refere, na verdade, ao então comandante do Segundo Exército, Ednaldo D'Ávila Melo. O incidente que precipitou sua demissão por Geisel foi o assassinato de Manuel Fiel Filho, que aconteceu menos de três meses depois do assassinato de Vladimir Herzog, em condições similares.

2. Tarso refere-se possivelmente ao resultado da votação da Arguição de Descumprimento de Preceito Fundamental (ADPF) 153, em abril de 2010, apresentada ao Supremo Tribunal Federal pelo Conselho Federal da Ordem dos Advogados do Brasil com o questionamento da aplicação da anistia aos representantes do Estado que, durante o regime militar, praticaram atos de tortura. Prevaleceu a interpretação de que também eles estavam anistiados.

3. Referência à homenagem de Bolsonaro a Carlos Alberto Brilhante Ustra durante a votação do impeachment de Dilma Roussef, em abril de 2016.

4. Referência a boletim número 15 da Associação Democrática Nacionalista de Militares [ADNAM], publicado em julho-agosto de 1985.

5. Referência à audiência pública intitulada "Limites e Possibilidades para a Responsabilização Jurídica dos Agentes Violadores de Direitos Humanos durante Estado de Exceção no Brasil", promovida pelo Ministério da Justiça em 31 de julho de 2008.

6. Trata-se de palestra intitulada A participação das Forças Armadas no governo: um novo normal? Disponível em: https://www.youtube.com/watch?v=ddtR3ZMxisA\&featur e=youtu.be\&fbclid=IwAR3k8y4SQSIIka1YnVcJHA7eutao9 


\section{ENTREVISTA COM TARSO GENRO}

REVISTA ESTUDOS POLÍTICOS Vol. 10 | N.2 ISSN 2177-2851

Cristina Buarque de Hollanda

zPZhMMjLjf4Ocs-0OF7dx-NDWMES80. Acesso em 5 de maio de 2020. 